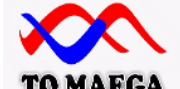

TOMAEGA
To Maega $\mid$ JurnalPengabdianMasyarakat

Agustus 2021, Vol.4., No.2, hal. 160-169

$\operatorname{ISSN}(P): 2622-6332 ; \operatorname{ISSN}(E): 2622-6340$

http://www.ojs.unanda.ac.id/index.php/tomaega

\title{
Revitalisasi Nilai-Nilai Islam pada Anak-Anak Jamaah Mushala di Gampong Jawa, Kota Langsa, Aceh Melalui Kegiatan Pesantren Kilat
}

\author{
Renza Ananda Putra ${ }^{1}$, Dedy Surya ${ }^{2, *}$ \\ ${ }^{1}$ IImu al-Qur'an dan Tafsir,Fakultas Ushuluddin, Adab dan Dakwah Institut Agama Islam Negeri \\ Langsa \\ ${ }^{2}$ Bimbingan dan Konseling Islam, Fakultas Ushuluddin, Adab dan Dakwah Institut Agama Islam \\ Negeri Langsa \\ *Correspondent Email: dedysurya@iainlangsa.ac.id
}

Article History:

Received: 18-01-2021; Received in Revised: 15-03-2021; Accepted: 23-04-2021

DOI: http://dx.doi.org/10.35914/tomaega

\begin{abstract}
Abstrak
Revitalisasi nilai-nilai agama merupakan salah satu hal yang penting dalam kehidupan karena dengannya maka kehidupan akan terasa menjadi aman, nyaman, dan tenteram. Menanamkan nilai-nilai agama kepada anak sedini perlu dilakukan karena apabila anak-anak sudah memahami nilai-nilai agama sejak usia dini maka akan membuat mereka lebih mudah untuk mengimplementasikan ajaran agama dalam kehidupannya kelak. Melihat kenyataan dewasa ini bahwa banyak anak yang kurang mendapatkan pendidikan agama yang cukup, maka penulis berupaya untuk menanaman nilai-nilai agama pada anak usia dini melalui kegiatan pesantren kilat. Penelitian ini dilakukan di Gampong Jawa, Kota Langsa, Provinsi Aceh. Dalam kegiatan ini, anak-anak diajarkan pendidikan agama, meliputi Akidah Akhlak, Fiqh, Sejarah Kebudayaan Islam, dan Qira'ah. Materi Akidah Akhlak diberikan sebagai upaya untuk memperbaiki etika dan moral. Pembelajaran Fiqh bertujuan untuk memberikan pemahaman anak-anak akan syariat serta kegiatan amaliyah lainnya seperti shalat dan sebagainya. Pengajaran al-Quran diberikan melalui kegiatan tadarusan dan yasinan berjamaah untuk mengasah kemampuan peserta didik untuk mampu membaca al-Quran dengan baik dan benar. Hasil dari kegiatan ini menunjukkan adanya peningkatan pengamalan nilai-nilai Islam pada anak-anak di Gampong Jawa, Kota Langsa, Aceh. Hal ini terlihat dari antusias mereka dalam beribadah terutama ibadah shalat fardhu berjamaah serta tatakrama saat bergaul dengan teman sebaya serta kepada orang tua.
\end{abstract}

Kata Kunci: revitalisasi, nilai-nilai agama, akidah akhlak, fiqh, Pesantren kilat

\section{Abstract}

The revitalization of religious values is one of the important things in life because with it life will feel safe, comfortable, and peaceful. Instilling religious values to children as early as necessary because if children already understand religious values from an early age it will make them easier to implement religious teachings in their lives in the future. Seeing the fact today that many children do not get enough religious education, the author seeks to plant religious values in early childhood through flash boarding activities. This research was conducted in Gampong Java, Langsa City, Aceh Province. In this activity, children are taught religious education, including Akhlak, Fiqh, Islamic Cultural History, and Qira'ah. Akhlak Atheism material is given as an effort to improve ethics and morals. Fiqh learning aims to provide children with an understanding of Shariah and other religious activities such as prayer 
and so on. The teaching of the Quran is given through "tadarusan" (reading Quran aloud together) and "yasinan" (reading Soorah Yaaseen) activities to hone the ability of learners to be able to read the Quran properly and correctly. The results of this activity showed an increase in the practice of Islamic values in children in Gampong Jawa, Kota Langsa, Aceh. This can be seen from their enthusiasm in worship, especially the worship of congregational obligatory prayers and manners when associating with peers as well as to parents.

Key Word: revitalization, religious values, akidah akhlak, fiqh, Pesantren kilat

\section{Pendahuluan}

Banyak fenomena perilaku yang menyimpang sering kita lihat dalam kehidupan sehari-hari terjadi pada anak-anak, seperti kurangnya akhlak, lemahnya akidah, serta sedikitnya pengetahuan dalam bidang agama. Perubahan-perubahan dinamika masalah kehidupan merupakan sesuatu yang harus dihadapi dalam kehidupan bermasyarakat, berbangsa dan bernegara. Perubahan ini disebabkan dengan arus globalisasi yang dipengaruhi oleh pemikiran luar (Anggun, 2013). Hal ini terjadi juga disebabkan karena kurangnya kesadaran para akademisi akan betapa pentingnya perannnya kepada masyarakat untuk merevitalisasi nilai-nilai agama kepada generasi muda bangsa. Revitalisasi diartikan sebagai upaya menghidupkan kembali sesuatu yang sudah mengalami kemunduran (Sumardjoko, 2013) Artinya, tradisi dan kebiasaan anak-anak haruslah terus menerus berada dalam ranah nilai-nilai keagamaan hingga generasi berikutya dalam makna yang hakiki, sehinggga nilai-nilai agama akan tetap terpelihara dari generasi ke generasi.

Anak-anak sebagai generasi penerus bangsa harus mendapat perhatian dan pembinaan yang baik, karena nasib bangsa tergantung pada anak-anak mudanya. Maka dari itu salah satu hal yang harus dibangun oleh bangsa adalah nilai-nilai keagamaan yang mereka anut, sehinga menjadikan bangsa yang berwibawa, berakhlak mulia, berkarakter, dan beretika sesuai dengan jati diri bangsa (Kurniawan, 2017; Manuhung dkk, 2018). Maka dari itu kewajiban kita sebagai generasi yang lebih tua adalah untuk mendidik anak-anak agar tetap terkontrol dalam bingkai nilai-nilai agama melalui pendidikan sebagai upaya bimbingan yang dilakukan secara sadar oleh seorang pendidik (Hasbullah, 2015). Mendidik merupakan salah satu usaha pelestarian moral yang sangat berpengaruh dalam kehidupan (Inawati, 2017). Seorang pemikir Aristoteles pernah mengatakan masyarakat yang budayanya tidak memperhatikan pentingnya mendidik akan menjadi masyarakat yang terbiasa akan kebiasaan buruk (Hidayat, 2015).

Pemandangan seperti ini juga terjadi di lingkungan masyarakat di Gampong Jawa, Kota Langsa, Aceh. Mudah ditemukan anak-anak yang terlalai akan kecanggihan teknologi sehingga lupa akan penting belajar agama dan memahaminya serta mengimplementasikan ke dalam kehidupannya sehari-hari. Keadaan seperti ini diperparah oleh adanya wabah Covid-19, yang menyebabkan kegiatan belajar mengajar di sekolah harus ditutup sementara. Sehingga semakin besar kesempatan anak-anak untuk terpapar oleh kegiatan yang tidak berguna yang akan merusak masa depan mereka 
Demi mengantisipasi akan terjadinya kedangkalan pengetahuan pada anak-anak akan agama, maka salah satu solusi yang ditawarkan adalah dengan diadakannya program pesantren kilat. Pesantren kilat secara umum yaitu sebuah lembaga pembelajaran agama yang di dalamnya terdapat proses belajar dan mengajar dengan menggunakan sarana masjid atau madrasah dan dilaksanakan dalam waktu yang singkat. Sedangkan dalam pengertian khusus pesantren kilat bermakna sebuah wahana alternatif pendidikan dalam rangka memantapkan kimanan dan ketakwaan kepada Allah Swt (Lisa dkk., 2020). Kegiatan pesantren kilat biasanya dilaksanakan khusus di bulan Ramadhan, karena dengan momen Ramadhan diharapkan nilai-nilai pendidikan dalam ibadah puasa dapat melatih anak-anak untuk mengendalikan hawa nafsu dan kesabaran untuk menjadi pribadi yang amanah, bertakwa, beriman, dan menumbuhkan sikap persatuan antar sesama (El-Sutha, 2014).

Kegiatan pengabdian berbentuk pesantren kilat ini memanfaatkan momen libur sekolah antarsemester, dengan harapan kegiatan ini dapat menstimulus pemahaman dan keinginan anak-anak untuk mempelajari agama serta menghidupkan kembali nilai-nilai Islam sehingga terwujudnya perilaku ke arah yang lebih baik,sesuai dengan nilai-nilai ajaran Islam.

\section{Metode}

Metode yang digunakan dalam pengabdian untuk merevitalisasi nilai-nilai agama pada anak-anak jamaah mushala di Gampong Jawa, Kota Langsa adalah pendidikan masyarakat dengan penyuluhan yang bertujuan untuk meningkatkan pemahaman dan menghidupkan nilai-nilai agama pada diri anak-anak di Gampong Jawa, Kota Langsa. Kegiatan ini dilaksanakan selama 14 hari, terhitung dari tanggal 28 Desember 2020 sampai dengan tanggal 10 Januari 2021.

Ada beberapa tahapan yang harus dilakukan untuk menjalankan program pengabdian yang bertajuk pesantren kilat ini. Adapun tahapan-tahapanya adalah sebagai berikut:

a. Tahap persiapan

Di tahap ini ada beberapa hal yang dilakukan, di antaranya: pertama. melakukan survei mengenai situasi dan kondisi faktual anak-anak dan masyarakat, melihat bagaimana kondisi minat dan budaya keislaman masyarakat dan anak-anak, memperhatikan apa saja yang dapat menghambat dan mendorong masyarakat dan anak-anak untuk menghidupkan nilai-nilai Agama dalam kehidupan sehari-hari. Pada tahap ini juga sekaligus dilakukan proses sosisalisasi kepada masyarakat mengenai kegiatan pengabdian ini. Kedua, melakukan penyusunan program kegiatan yang akan dilaksanakan. Dari tahapan-tahapan tersebut, penulis melibatkan masyarakat dalam proses komunikasi agar menuju pemahaman yang sama dengan masyarakat. Adapun sasaran program pesantren kilat liburan sekolah ini adalah anak-anak jamaah Mushala al-Ikhlas, Gampong Jawa, Kota Langsa. Aceh.

b. Pelatihan 
Pelatihan dilakukan melalui proses belajar dan mengajar di program pesantren kilat ini. Dengan adanya pelatihan maka peserta pesantren kilat mengetahui apa-apa saja yang harus mereka ikuti dan lakukan.

c. Pendampingan

Penulis melakukan pendampingan kepada peserta pesantren kilat di setiap proses kegiatan yang berlangsung. Sehingga dengan adanya pendampingan peserta dapat memahami betul apa-apa saja yang harus di perbuat.

d. Evaluasi

Tahap evaluasi ini dilakaukan setelah kegiatan pengabdian berakhir. Hal ini bertujuan untuk melihat dampak, manfaat, dan tingkat keberhasilan yang dicapai dari program pesantren kilat libur sekolah di Mushala al-Ikhlas Gampong Jawa, Kota Langsa, Aceh.

\section{Hasil dan Pembahasan}

Program pengabdian masyarakat ini mempunyai target untuk meningkatkan, menanamkan dan menghidupkan nilai-nilai agama kepada anak-anak jamaah mushala al-Ikhlas gampong Jawa, Kota Langsa. Strategi yang digunakam untuk menjalankan pengabdian ini terdiri dari beberapa tahapan, diantaranya: (1) Tahap survei yang dilakukan untuk mengetahui lokasi dan anak-anak yang ada di Gampong Jawa, kota Lings. (2) Tahap kerja sama dengan melakukan konfirmasi dan meminta izin kepada orang tua setempat untuk melakukan kegiatan pengabdian ini. (3) Tahap Pendataan anak-anak sebagai peserta program pesantren kilat. (4) Tahap pelaksaan dengan memberikan materi-materi pesantren kilat di Mushala al-Ikhlas Gampong Jawa, Kota Langsa.

Materi-materi yang diajarkan pada program ini mencakup Akidah Akhlak, Fiqh, Sejarah Kebuadayaan Islam, dan al-Qur,an. Pembelajaran yang disampaikan disesuaikan dengan $\mathrm{k}$ perkembangan anak didik dan dengan pembelajaran yang menarik agar kegiatan ini berpusat pada anak (Huda, dkk., 2020)

Selain itu, anak-anak juga mengikuti kegiatan pembacaan Yaasiin berjamaah setiap malam Jumat. Adapun penjelasan singkat mengenai materi-materi yang disampaikan adalah sebagai berikut:

a. Akidah Akhlak

Akidah secara umum berarti keyakinan, keimanan, kepercayaan secara mendalam pada keesaan Allah Swt. sebagai Tuhan yang Maha Kuasa. Akhlak adalah wujud realisasi dan aktualisasi dari akidah seseorang (Wahyudi, 2017). Dengan memberikan pendidikan akidah akhlak ini, diharapkan anak-anak jamaah Mushala al-Ikhlas, Gampong Jawa, Kota Langsa, Aceh ini dapat meniliki akidah yang lurus dan benar, serta menjadikan mereka generasi generasi yang memiliki budi pekerti yang baik. 


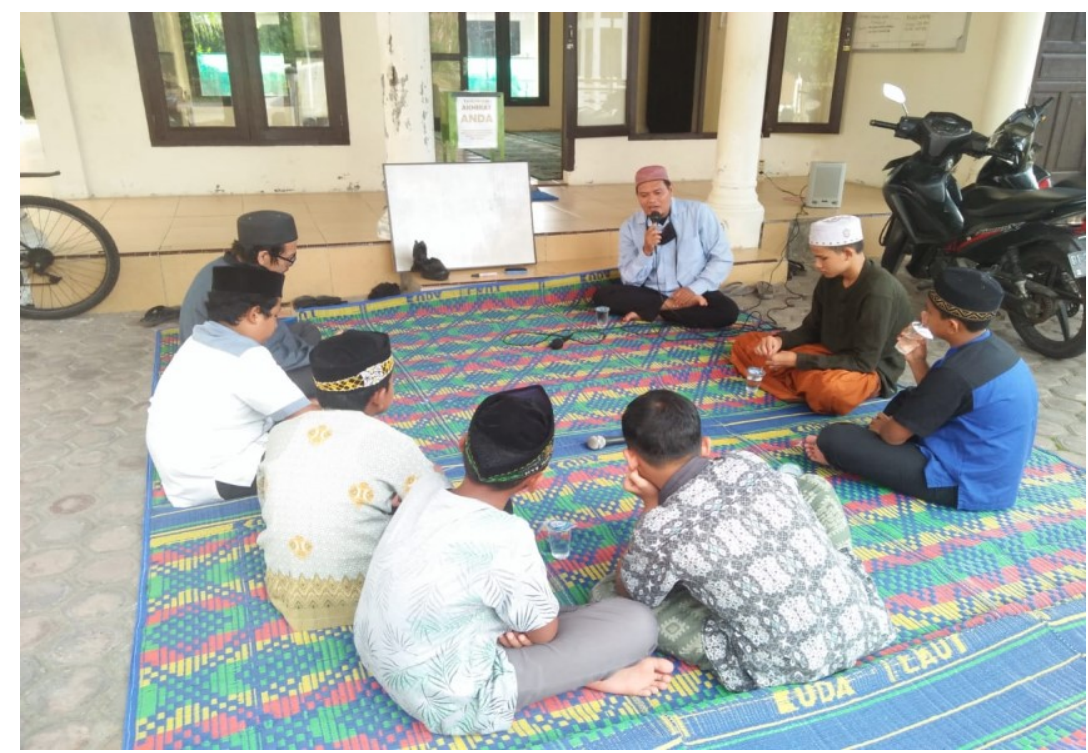

Gambar 1. Kegiatan pengajaran Akidah Akhlak

\section{b. Fiqh Ibadah}

Term fiqh ibadah terdiri dari dua kata yaitu fiqh dan ibadah. Secara etimologi Islam, fiqh berasal dari kata faqiha-yafqahu-fiqhan yang berarti mengetahui memahami, mendalami sesuatu secara mutlak. Jadi, fiqh ialah memahami aturanaturan (syariat) Islam secara mutlak. Kata ibadah secara bahasa berarti menyembah, menghambakan diri, dan mengabdi. Sedangkan menurut istilah ibadah adalah suatu ritual yang dilakukan oleh seorang hamba dalam rangka mengabdi, menyembah, dan menghambakan diri kepada Allah Swt (Yaqin, 2016).
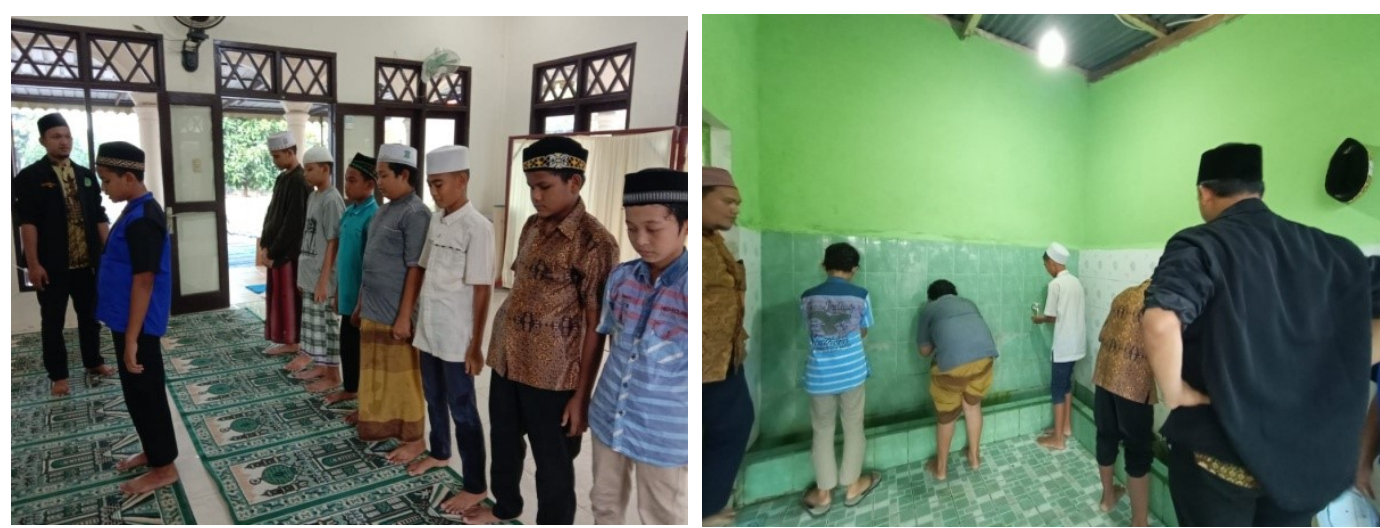

Gambar 2. Kegiatan praktik wudhu' dan shalat

Dengan adanya pengajaran tentang fiqh ibadah diharapkan kepada anak-anak jamaah mushala al-Ikhlas Gampong Jawa, Kota Langsa, Aceh memahami bagaimana cara-cara bersuci, mengenal macam-macam najis, dan tata cara shalat. Dengan begitu anak-anak memiliki pengetahuan yang cukup saat melakukan ibadah kepada Allah SWT.

c. Sejarah Kebudayan Islam 
Berkembangnya teknologi, menyebabkan banyak anak yang lalai dan lupa akan sejarah. Sejarah Kebudayaan Islam menyajikan berbagai kisah-kisah masa lalu tentang bagaimana Islam, masyarakat, peradaban, dan kebudayaannya sejak zaman Nabi Muhammad Saw, khulafaur rasyidin, dinasti-dinasti yang berkuasa setelahnya, hingga Islam pada zaman modern. Dengan mempelajari Sejarah Kebudayaan Islam, banyak manfaat dan hikmah yang dapat diperoleh.

Melalui sejarah, seseorang dapat mengambil hikmah dari kejadian-kejadian yang terjadi di masa lalu yang dapat meningkatkan ketakwaan kepada Allah Swt. Dengan mengetahui sejarah Islam, seperti bagaimana Nabi Muhammad Saw, khulafaur rasyidin dan tokoh-tokoh muslim setelahnya dalam berjuang menyebarkan dan mempertahankan ajaran Islam hingga saat ini, sehingga muncul perasaan lebih menghargai perjuangan mereka dan berimplikasi pada peningkatan ketakwaan kita kepada Allah Swt. sebagai bentuk penghargaan dan penghormatan bagi mereka. Sejarah jugad dapat diambil pelajaran sebagai pertimbangan ketika hendak mengambil keputusan dalam suatu perkara. Tidak jarang hal-hal yang terjadi di masa lalu kembali terjadi di masa sekarang. Dengan mengetahui apa yang terjadi di masa lalu, seseorang dapat mengambil sebuah keputusan akan hal yang terjadi di masa sekarang dengan tepat. Misalnya, jika terjadi sesuatu persoalan yang sama atau hampir sama di masa sekarang dengan yang ada di masa lalu, maka cara tersebut dapat diadopsi dengan sedikit penyesuaian dengan konteks zaman masa kini. Selain itu sejarah dapat juga dijadikan media suri teladan serta media untuk menumbuhkan rasa cinta kepada Islam.

Dengan memberikan pelajaran tentang sirah nabawiyah diharapkan anak-anak peserta pesanten kilat dapat lebih mengenal Rasulullah saw, dan mengetahui bagaimana pahit manisnya perjuangan dalam menegakkan kalimat tauhid sehingga ikut tumbuh rasa empati sehingga menjadikan meraka sebagai generasi-generasi penerus bangsa dan agama yang memiliki kekokohan iman dan hati dalam melanjutkan dakwah Islam.

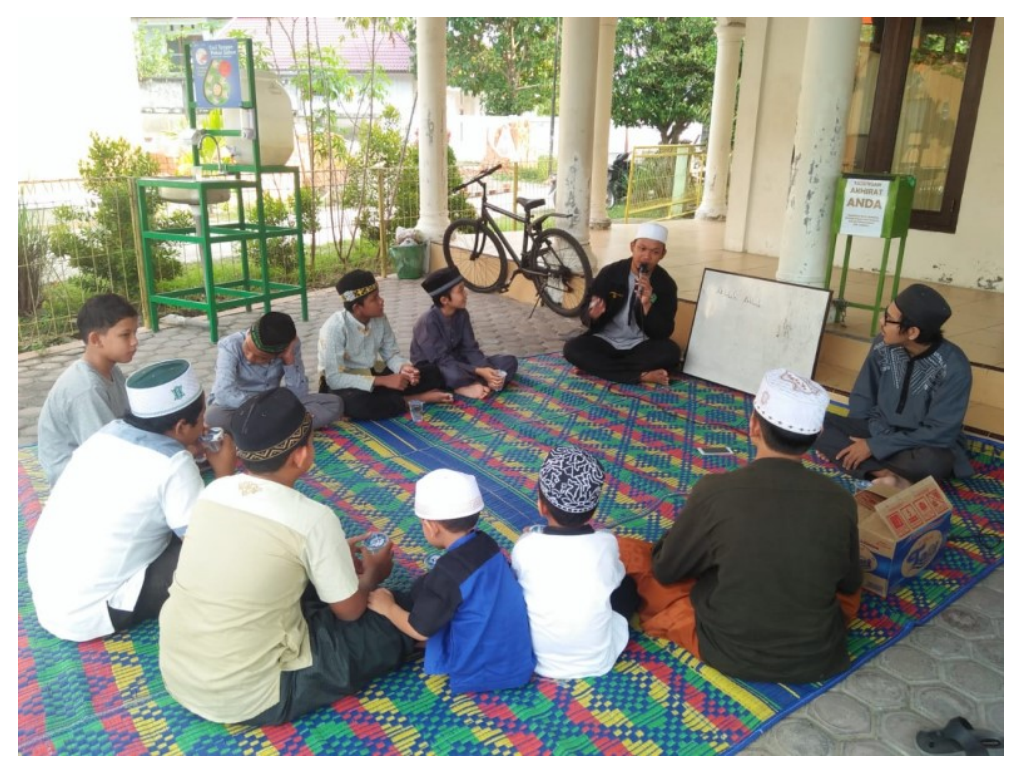

Gambar 3. Kegiatan pembelajaran tentang Sejarah Kebudayaan Islam 
d. Belajar al-Quran

Banyak kita lihat kemampuan dalam membaca al-Qur'an anak-anak masih terbata-bata, makharijul huruf yang tidak sesuai, serta tidak paham dengan kaidah tajwid. Di program kegiatan pengabdian ini penulis memfasilitasi anak-anak untuk belajar tahsin dan tajwid al-Qur'an, sehinga anak-anak dapat belajar membaca alQur'an dengan baik dan benar. Manfaat mempelajari ilmu tajwid ini di antaranya adalah: dapat melafadzkan bacaan al-Qur'an dengan fasih, menjaga keaslian alQur'an, mengharapkan ridha Allah Swt. (al-Fadhli, 2019) sebagaimana firman Allah dalam al-Quran: “...dan bacalah al-Qur'an dengan baik dan benar...) (QS. Al-Muzammil: 6)
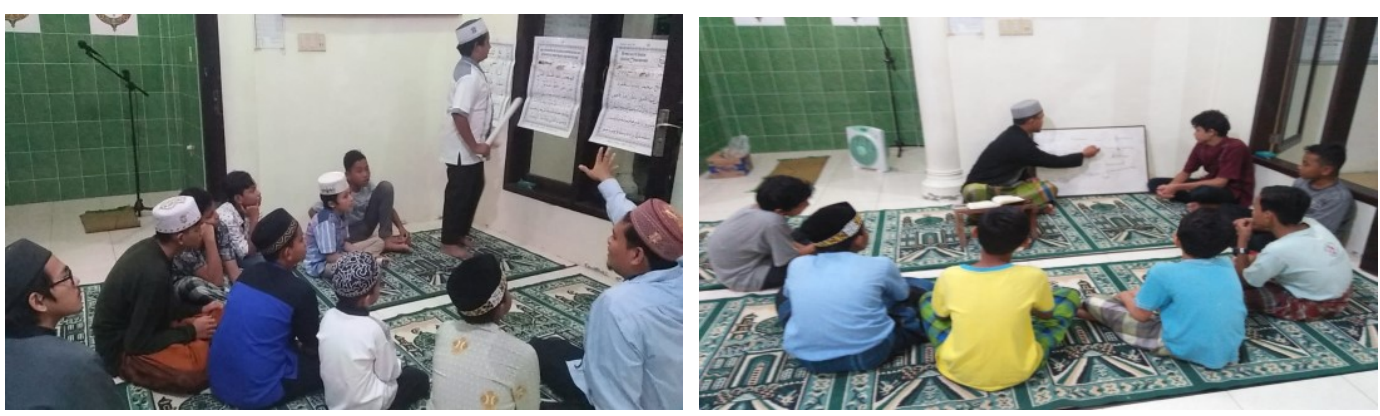

Gambar 4. Kegiatah tahsin al-qur'an

Tak sebatas itu, peserta juga diajak untuk melaksanakan program amaliyah wajib lainya seperti shalat berjamaah, tadarus berjamaah, membaca Surah Yaasiin berjamaah pada saat malam jum'at, dzikir dan do'a berjamaah.

Program pesantren kilat ini diisi oleh beberapa orang guru secara bergantian untuk mengisi materi materi sesuai dengan jadwal yang telah ditentukan. Tenaga pengajar yang mengisi pada program pesantren kilat adalah para dosen Institut Agama Islam Negeri Langsa dan juga melibatkan imam tetap Mushala Al-Ikhlas, Gampong Jawa Kota Langsa. Aceh. Lebih lanjut, mahasiswa Institut Agama Islam Negeri Langsa juga turut dilibatkan untuk menjadi pendamping pada peserta pesantren kilat.

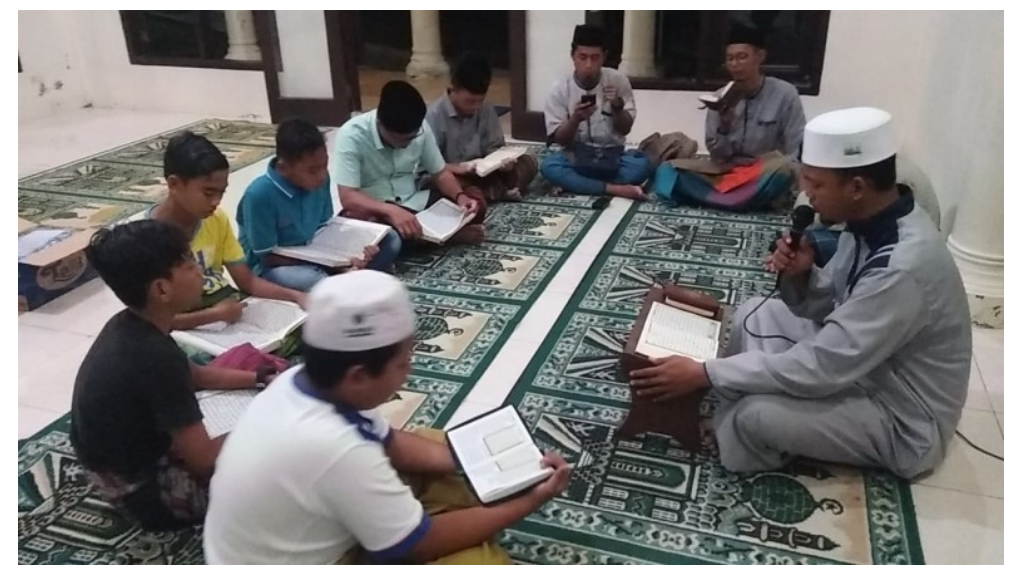

Gambar 5. Kegiatan tadarus, yasin, dzikir, dan do’a berjamaah 
Dalam pelaksanaan kegiatan pesantren kilat diupayakan untuk menciptakan suasana yang penuh kegembiraan, kekeluargaan, kerukunan, dan kebersamaan antar sesama peserta, mengingat kegiatan ini adalah pengganti liburan sekolah yang mereka miliki. Di program ini anak-anak juga di ajarkan dan dibimbing serta membiasakan untuk saling menghormati, saling menghargai, saling mencintai, saling menyanyangi kepada sesama teman serta hormat dan patuh kepada orang tua dan guru.

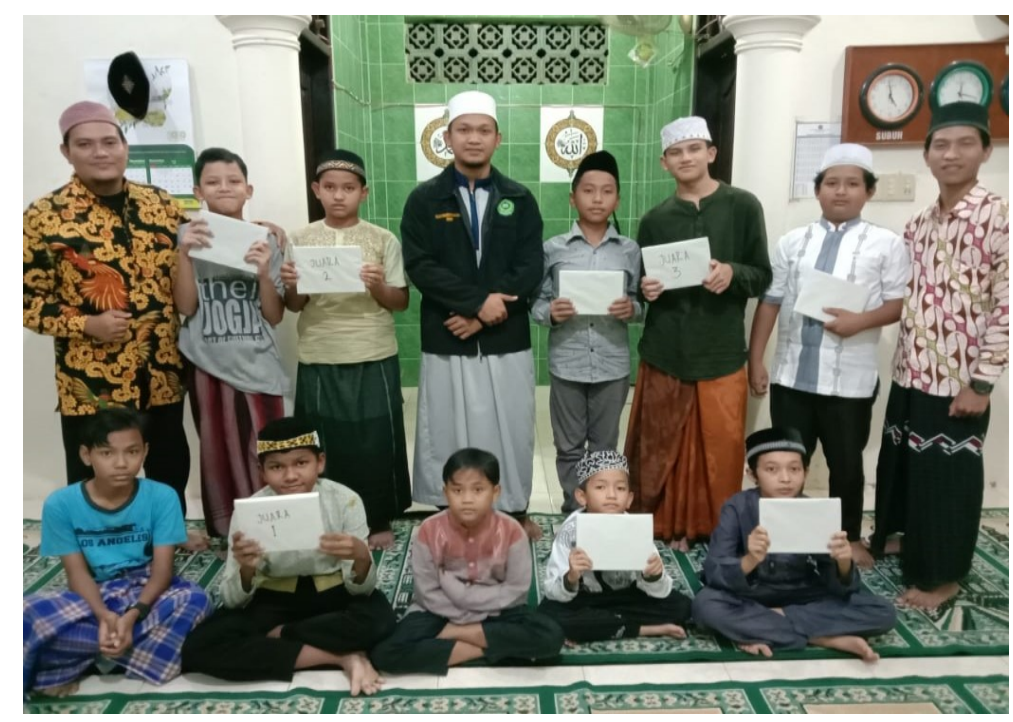

Gambar 6. Penutupan kegiatan pesantren kilat libur sekolah

Untuk mendapatkan umpan balik serta tolok ukur dampak kegiatan ini, pada akhir kegiatan pesantren kilat dilakukan evaluasi. Evaluasi dilakukan dengan melakukan wawancara pada orang tua yang telah menitipkan anaknya pada kegiatan pesantren kilat ini. Melalui wawancara tersebut, para orang tua menunjukkan respon yang positif terhadap pelaksanaan kegiatan pesantren kilat ini. Para orang tua mengungkapkan bahwa kegiatan ini memberikan pengaruh positif terdapat pengamalan nilai-nilai agama dan praktik ibadah anak-anak mereka. Hal ini terlihat dari antusias mereka untuk shalat berjamaah di masjid. Mereka menambahkan bahwa kemampuan membaca al-Quran anak-anak telah meningkat. Selain itu, hal yang paling mneggembirakan adalah sopan santun dalam bertutur kata dan berperilaku pada orang tua juga terlihat sangat signifikan.

\section{Kesimpulan}

Pelaksanaan program pesantren kilat libur sekolah bagi anak-anak jamaah Mushala al-Ikhlas, Gmapong Jawa, Kota Langsa yang masih duduk di bangku sekolah bertujuan untuk mengajarkan, menanamkan, serta menghidupkan nilai-nilai agama pada diri setiap anak-anak sebagai penerus bangsa dan negara. Selain itu kegiatan pesantren kilat di masa libur sekolah ini juga memiliki tujuan utama untuk dapat meningkatkan pemahaman, penghayatan, dan pengamalan siswa tentang ajaran agama Islam sehingga 
menjadi manusia muslim yang beriman dan bertakwa kepada Allah SWT serta berakhlak mulia dalam kehidupan pribadi, bermasyarakat, berbangsa, dan bernegara. Serta, agar dapat menerapkan dan mengamalkan ajaran Islam dalam kehidupan seharihari dalam rangka membentuk mental spiritual yang tangguh, kokoh, dan mampu menghadapi tantangan-dan pengaruh negatif, baik yang datang dari dirinya pribadi maupun dari luar dirinya.

\section{Ucapan Terimakasih}

Ucapan rasa syukur kepada Allah Swt. atas kuasaNya sehingga kegiatan pengabdian ini dapat berjalan lancar. Terima kasih kami sampaikan kepada Rektor dan Ketua Lembaga Penelitian dan Pengabdian kepada Masyarakat Institut Agama Islam Negeri Langsa atas dukungannya. Terima kasih juga disampaikan kepada masyarakat Gampong Jawa Muka, Kota Langsa, Aceh yang telah menerima dan mendukung berjalannya kegiatan pengabdian ini sehingga dapat berjalan sesuai yang telah direncanakan

\section{Daftar Pustaka}

Al-Fadhil, M. L. (2019). Syarah matan Tuhfatul Athfal: Penjelasan hukum tajwid dan dasar-dasar tajwidul huruf. Sukoharjo: Nur Cahaya Ilmu.

Anggun, G. (2013). Pentingnya menumbuhkan pendidikan moral di era globalisasi, https://goenable.wordpress.com/pentingnya-menumbuhkan-pendidikan-moraldi-era-globalisasi

El-Sutha, S. H. (2014). Tiada bulan seindah Ramadhan. Jakarta: Kalam Mulia

Hasbullah. (2015). Dasar-dasar ilmu pendidikan. Jakarta: PT. RajaGrafindo Persada.

Hidayat, O. S. (2015). Metode pengembangan moral dan nilai-nilai agama. Tangerang: Universitas Terbuka

Huda, N., Madiana, N., \& Imayah (2020) Strategi pembelajaran bagi guru di Lembaga Pendidikan Islam Anak Sholeh Pepelegi, Sidoarjo. To Maega | Jurnal Pengabdian Masyarakat 3(2), 111-121.

Inawati, A. (2017). Strategi pengembangan moral dan nilai agama untuk anak usia dini. Al-Athfal: Jurnal Pendidikan Anak, (3)1, 51-64

Kurniawan, M. (2017). Membangun generasi bangsa melalui pendidikan moral dan etik, https://www kompasiana.com/www.kernianingsih.com/ membangungenerasi-bangsa-melaluipendidikan- moral-dan-etika

Lisa, H., Mardiah., \& Napratilora, M. (2020). Program pesantren kilat untuk meningkatkan motivasi ibadah siswa. ABDIMASY: Jurnal Pengabdian Dan Pemberdayaan Masyarakat, 1(2), 63-74.

Mannuhung, S., Tenrigau, A. M., \& D, D. (2018). Manajemen Pengelolaan Masjid dan Remaja Masjid di Kota Palopo. To Maega: Jurnal Pengabdian Masyarakat, 1(1), 14-21. 
Sumardjoko, B. (2013). Revitalisasi Nilai-Nilai Pancasila Melalui Pembelajaran Pkn Berbasis Kearifan Lokal Untuk Penguatan Karakter Dan Jati Diri Bangsa. Jurnal Varidika: Kajian Penelitian Pendidikan (25)2, 110-123.

Wahyudi, D. (2017). Pengantar akidah akhlak dan pembelajarannya. Yogyakarta: Lintang Rasi Aksara Books.

Yaqin, A. (2016). Fiqh Ibadah: kajian konperhensif tata cara ritual dalam Islam. Pamekasan: Duta Media Publishing. 